\title{
Naurettava sukupuoli
}

\author{
KOOMISEN RAKENTUMINEN \\ BILLYS PIZZA - M AINOSELOKUVASSA
}

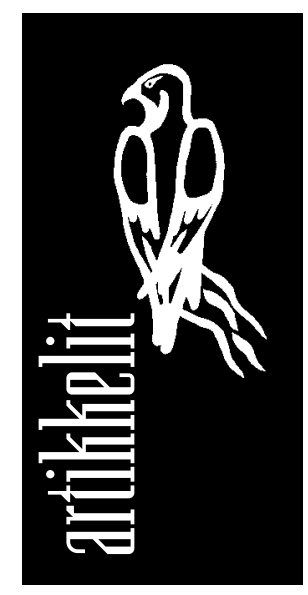

Mainoselokuvan alussa kaunis nuori nainen istuu yksin hillityn tyylikkääseen iltapukuun pukeutuneena tasokkaan näköisessä ravintolassa. Hän vilkuilee kelloaan ja katselee ympärilleen kuin etsien jotain. Samaan aikaan nuori erittäin hoikka, tai pikemminkin luiseva, mies on pukeutumassa kotonaan peilin edessä. Peilin vieressä on kehystetty kuva Dolly Partonista ja takana olevaa seinää koristaa Richard Gere American Gigolo -elokuvajulisteessa. Vaikka mies on äärimmäisen tyytyväisen näköinen peilistä heijastuvaan näkymään, hän ei osaa päättää, mitä laittaisi ylleen. Vauhdikas poseeraus ja vaatteiden vaihto peilin edessä saa miehen unohtamaan ajan kulun. Nainen soittaa ravintolasta miehelle, joka on jo lähdössä ulos, kun keittiön leivänpaahtimen kiiltävästä pinnasta heijastuu jotain pysäyttävää. Mies istuu alas ja jää paahtimen eteen tarkastelemaan tyytyväisenä omia kasvojaan. Illalliseksi löytyy jääkaapista einespitsa. Ravintolaan yksin unohdettu nainen huokaa.

Edellä kuvattu MTV3:n syksyllä 1999 esittämä Billys Pizza (jatkossa BP) -mainoselokuva edustaa kahdessa erityisessä suhteessa melko tyypillistä mainoselokuvaa. Ensinnäkin, se käyttää komiikkaa merkitysten rakentelussaan. Komiikan

Artikkelissa tarkastellaan mainonnan käyttämää komiikkaa. Aihetta lähestytään komiikan mekanismien suunnasta ja erityisesti sen suhteen, miten komiikka kytkeytyy sukupuolen esittämiseen. Analyysin kohteena on koomisen rakentuminen, se miten mainonnassa tuotetaan koomista. Tarkastelu fokusoituu mainonnan sukupuolikuvastoon, siihen millaisia esityksiä mainonnassa komiikan keinoin rakennetaan mieheydestä ja naiseudesta. Kyseessä on tapaustutkimus, jonka aineiston muodostaa MTV3-kanavalla vuosituhannen vaihteessa esitetty Billys Pizza -mainoselokuva. Analyysimetodina käytetään Roland Barthesin semioottista koodistoa ja komiikan teorioihin pohjautuvaa lähilukua. Analyysi paljastaa ensinnäkin koomisen monisyisyyden - sen, että jo yhdestä mainoselokuvasta löytyy useita eri mekanismeja, joilla asia saadaan näyttämään naurettavalta. Toiseksi, Billys Pizza -mainoksen analyysi tuo esiin sen ambivalenssin, joka sisältyy mainonnan sukupuolirepresentaatioihin. Mainoksessa tullaan komiikan keinoin sekä myötäilleeksi että tietyin osin kyseenalaistaneeksi stereotyyppistä sukupuolikuvastoa. suhteellisen suuri osuus nykymainonnassa näkyy esimerkiksi siinä tausta-aineistossa, josta BP-mainos on valittu. Tämän artikkelin pohjana on ruumiillisuutta ja mainontaa koskeva väitöskirjatutkimus (Sarpavaara 2004), jossa analysoitiin 167 MTV3-kanavalla syksyllä 1999 esitettyä mainoselokuvaa. Näistä melko moni, 43 mainosta, luokittui koomisia elementtejä sisältäviksi. ${ }^{1}$ Komiikan käytön yleisyyden nykymainonnassa on huomioinut myös Nando Malmelin (2003, 97), jonka mukaan se on jo sitä luokkaa, että komiikasta on tullut vallitseva periaate mainonnan suunnittelussa. Leena-Maija Rossi $(2003,83)$ puolestaan on esittänyt, että mainoskomiikassa erityisesti sukupuolivitsit näyttävät olevan keskeinen alue. 
BP-mainosta voidaankin pitää tyypillisenä mainoselokuvana myös siksi, että se sisältää representaatioita sukupuolesta. Mainonta on yksi keskeinen paikka nykyisessä mediakulttuurissa, jossa tuotetaan käsityksiä siitä, mitä on olla nainen ja mitä on olla mies. Nykyisin yhä suurempi osa sukupuolirepresentaatioista on mainosten välittämiä, jopa siinä määrin, että sukupuolen on nähty muodostuneen mainonnalle jo pakkomielteeksi (Jhally 1987, 135). Mainonnan sukupuolirepresentaatioiden tutkimisen mielekkyys nousee siitä Judith Butlerin (1990) ajatuksesta, jonka mukaan sukupuoli ei ole niinkään olemista vaan teke-
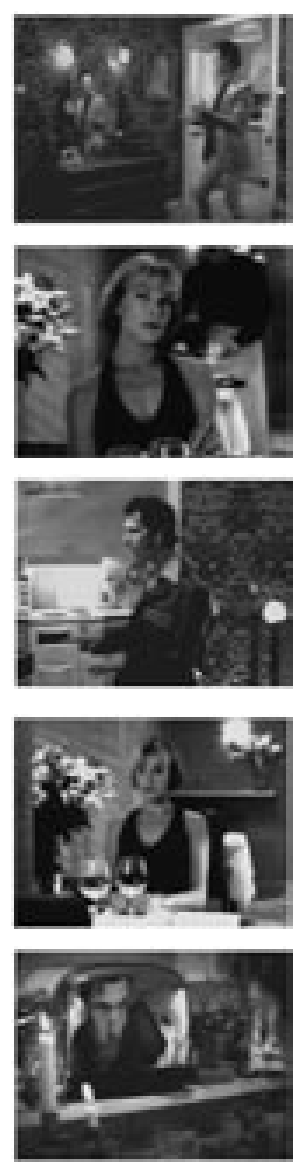
mistä - performanssi, joka tapahtuu toistamalla kulttuurisesti vakiintuneita eleitä. Tänä päivänä mainonta on keskeisimpiä paikkoja, jossa näitä eleitä toistetaan. Teresa de Lauretista (1987) myötäillen mainontaa voidaan tarkastella sukupuoliteknologiana, joka tuottaessaan esityksiä sukupuolesta samalla jäsentää ja konstruoi, uusintaa ja muovaa uudelleen käsityksiä siitä, mikä on naisellista ja mikä miehekästä. Tällaisena teknologiana mainonnalla on osaltaan valtaa kontrolloida ja juurruttaa sukupuolirepresentaatioita ja tuottaa sukupuolitettua subjektiutta ja kokemusta.

Tässä artikkelissa tarkastelun kohteeksi asettuu mainonnan käyttämä komiikka. Lähestyn komiikkaa analysoimalla niitä keinoja ja mekanismeja, joilla nykymainonta pyrkii synnyttämään naurua. Mainonnan komiikkaa tarkastelen erityisesti sen suhteen, miten koominen ja sukupuolen esittäminen kietoutuvat siinä toisiinsa. Tutkimuskysymykset ovat seuraavat: Miten - millaisin keinoin ja mekanismein - mainonnassa rakennetaan koomista? Millaisia esityksiä mainonnassa komiikan keinoin tuotetaan mieheydestä ja naiseudesta? Näihin kysymyksiin haen vastauksia case-tutkimuksen keinoin: analysoin komiikan käyttöä mainonnassa yhden tapauksen, edellä kuvatun BP-mainoselokuvan, kautta.

Etenen siten, että aluksi selvitän lyhyesti, mitä silloin tutkitaan kun tutkitaan koomista - millainen analyyttinen ero käsitteiden koominen ja huumori välillä voidaan tehdä. Tästä siirryn varsinaiseen analyysiin, BP-mainoksen yksityiskohtaiseen tarkasteluun. Analyysi etenee kaksivaiheisesti siten, että ensin asetan kyseisen mainoselokuvan semioottisen merkitysanalyysin kohteeksi, jossa hyödynnän ja sovellan Roland Barthesin koodistoa. Semioottinen lähestymistapa on valittu siksi, että se sopii paitsi mainonnan myös koomisen analyysiin, koska pohjimmiltaan koominen on semioottista, merkkeihin ja merkityksiin liittyvää (Neale \& Krutnik 1990, 70). Analyysin toisessa vaiheessa täydennän semioottista analyysiä erittelemällä mainoselokuvasta löytyviä koomisen mekanismeja. Tässä vaiheessa sovellan koomisen teorioita hakiessani vastauksia kysymykseen, miten koominen vaikutelma tässä pitsamainoksessa syntyy - miksi tämä mainos naurattaa tai miksi sitä katsellessa tuntuu siltä, että se ainakin yrittää naurattaa meitä. Sekä semioottista analyysiä että mekanismien analyysiä ohjaa kysymys sukupuolen tuottamisesta.

\section{Koominen vs. huumori}

Koomista, huumoria ja naurua käsittelevissä kirjoituksissa vallitsee käsitteellinen hajaannus. Tämän on nähty johtuvan muun muassa aihetta tutkivien tieteenalojen välisten keskusteluyhteyksien vähäisyydestä ja näiden ilmiöiden marginaalisesta asemasta tieteenalojen sisällä. Esimerkiksi huumoria on usein käytetty erityismerkitysten ohella yleiskäsitteenä, joka kattaa alan kaiken erityisyyden (koo- 
misen, naurun, ironian, vitsit, kaskut, komediat jne.). (Knuuttila 1992, 92-94.) Angloamerikkalaisessa tutkimuksessa onkin komiikkaa, huumoria ja naurua usein käytetty toistensa synonyymeinä viittaamaan mihin tahansa hauskaan ilmiöön tai asiaan (Frangén 1990, 2).

Vaikka koomisen ja huumorin erottaminen toisistaan ei ole ongelmatonta, niin analyyttinen ero käsitteiden välillä voidaan kuitenkin tehdä. Sanakirjan mukaan koominen on hilpeyttä herättävä, hullunkurinen, naurattava, lystikäs, hupaisa, naurettava. Huumorin sanakirja määrittelee leikillisyydeksi, kujeellisuudeksi, pilailuksi, leikinlaskuksi ja myötätuntoiseksi suhtautumiseksi koomisiin elämänilmiöihin. (CD-perussanakirja 1997.) Koominen näyttäisi siis viittaavan vahvemmin huumorin aiheuttajaan ja huumori puolestaan kokemukseen (vrt. Herkman 2000, 374-375). Tällaiseen erontekoon antaa mahdollisuuden myös K.S. Laurilan (1918, 285-286 ref. Knuuttila 1992, 95) jo jokin aika sitten tekemä luonnehdinta, jonka mukaan huumori on määrätynlainen suhtautumistapa elämään ja ilmiöihin, erityisesti koomisiin ilmiöihin. Koominen (tai koomillisuus, jota käsitettä Laurila käyttää) sen sijaan on Laurilan mukaan ulkokohtainen ominaisuus, jota voi olla muodoissa, asennoissa, liikkeissä, teoissa, tapahtumissa, tilanteissa, puheissa ynnä muissa. Koominen voidaankin lyhyesti määritellä joksikin, joka aiheuttaa tai jonka on tarkoitus aiheuttaa naurua (Neale \& Krutnik 1990, 15-16).

Koska en tarkastele tässä artikkelissa mainosten katsojissa synnyttämiä kokemuksia, vaan tutkin mainoselokuvien koomisia representaatioita kulttuurisina teksteinä, käytän käsitettä koominen (naurun aiheuttaja) huumorin (kokemus) sijaan. Tietenkin on niin, ettei koomisenkaan tutkija voi tarkastella kohdettaan ilman omaa kokemuksellista ja kontekstisidonnaista lähtökohtaansa. Kun jäljitetään koomisen mekanismeja tv-mainoksista, täytyy muistaa, että ihmiset nauravat eri asioille ja eri tavoin: koominen ja huumori ovat erotettavissa toisistaan ainoastaan rajatussa teoreettisessa mielessä. (vrt. Herkman 2000, 374-375.) Ei ole mitään takeita sille, että tv-mainosten koomisiksi tarkoitetut representaatiot ymmärretään koomisiksi tai että ne naurattaisivat. Koomisen tunnistaminen ja ymmärtäminen onkin sidoksissa kulttuurin jäsenyyteen ja sen mukanaan tuomaan tietoon. (Vrt. Eco 1985; Knuuttila 1992, 116; Neale \& Krutnik 1990, 64-65.) Koominen edellyttää aina paitsi havaitsemista myös tulkintaa (Knuuttila 1992, 119).

\section{Semioottinen merkitysanalyysi}

Yksi tapa analysoida mainoselokuvien merkitystuotantoa on soveltaa Roland Barthesin (1974) semioottista koodistoa. Tällöin mainoksia tarkastellaan audiovisuaalisina kulttuurisina teksteinä, joiden merkitsijät ryhmitellään niiden tapojen mukaan, joilla ne tuottavat merkityksiä. Vaikkei Barthes itse käyttänyt koodistoaan audiovisuaalisten tekstien analyysiin, niin sitä on sovellettu myös television mainoselokuvien analyysiin (ks. Blom 1995; Blom 1998; Sarpavaara 2001; Sarpavaara 2004).

Ensimmäinen näistä koodeista on toiminnan koodi, jolla analysoidaan toiminnan logiikkaa, sitä mitä tapahtuu. Toiminta BP-mainoksessa voidaan jakaa kolmeen jaksoon. Ensimmäistä niistä ei näytetä, mutta erilaisin elokuvallisin keinoin katsojalle annetaan vihjeitä siitä, että mies ja nainen ovat aiemmin sopineet tapaavansa ravintolassa. Toinen toiminnan jakso on odottelua ja valmistautumista: nainen istuu yksin kahdelle katetun pöydän ääressä kelloaan vilkuillen, mies puolestaan vasta etsii sopivia vaatteita kotonaan peilaillen. Mainos päättyy jaksoon, jossa mies unohtaa ravintolassa odottavan naisen ja jää kotiin syömään 
pitsaa seuranaan oma, leivänpaahtimen kyljestä heijastuva peilikuva. Mainoksen toiminta voidaan kokonaisuudessaan nähdä epäonnistuneeksi yritykseksi illastaa yhdessä.

Barthesin toinen koodi suuntaa katseen tarinan dynamiikan rakentumiseen - niihin kysymyksiin ja vastauksiin, ongelmiin ja ratkaisuihin, yllättäviin käänteisiin, jotka teksti tavalla tai toisella asettaa ja tuo esille. Tällaiset tekstin osat kuuluvat hermeneuttisen koodin alaisuuteen ja niiden kautta voidaan tarkastella myös sitä, mitä tarina haluaa viestiä. (Barthes 1974, 17.) BP-mainoksessa kerronnallista jännitettä pidetään yllä implisiittisellä kysymyksellä "saapuuko mies sovittuun tapaamiseen". Tarinan käänne antaa kielteisen vastauksen: mies jättää naisen yksin huokailemaan ravintolaan. Syyksi paljastuu miehen narsismia hipova itsekeskeisyys ja jääkaapista löytyvä einespitsa, joka korvaa ravintolaillan ravitsemuksellisen funktion. Mainoksen viestinä tuntuu olevan se, että kyseisen pitsan syöminen yksin kotona on antoisampaa kuin illanvietto hienossa ravintolassa upean naisen kanssa. Lisäksi tämä nopeavalmisteinen pitsa jättää enemmän aikaa todellisille kiinnostuksen kohteille.

Merkityksenannon pienimpiä elementtejä tarkastellaan Barthesin koodistossa seemeinä, lähtöinä jollekin valitulle näkökulmalle (Barthes 1974, 191). Televisiomainoksessa seemi syntyy esimerkiksi kuvakulmasta, valaistuksesta, tehosteäänestä, tietyn tyylisestä pukeutumisesta, ruumiin liikkeestä, eleestä, kasvojen ilmeestä tai hiusten mallista. Tällaisista yksittäisistä elementeistä rakentuu mainoksen ilmapiiri, odotushorisontti ja henkilöhahmot ominaisuuksineen (Blom 1998, 213). BP-mainoksen koomisuutta rakentavat seemit voidaan ryhmitellä miesrepresentaation, naisrepresentaation ja tapahtumapaikkojen (ravintola ja miehen koti) mukaan. Miehen olemus voisi viitata sliipatun teddy boy -tyylin retro-muunnelmaan. Vaatteet ja niiden valintaan käytetty aika kertovat ulkonäköön panostamisesta. Ruumiinliikkeet, eleet ja ilmeet (herkeämätön peilikuvan tarkkailu, tanssiminen ja poseeraaminen peilin edessä, omalle peilikuvalle kohotettu kulmakarva ja rennon vino hymy) kertovat hauskanpidosta, vahvasta itsetunnosta ja itsekeskeisyydestä. Miehen vartalon lähes anorektinen luisevuus yhdessä vaatetuksen ja kampauksen kanssa synnyttävät konnotaation rockkulttuurin dekadentista edustajasta. Richard Dyerin (2002, $109,112)$ mukaan avaintermi miesten kehoja arvioitaessa on lihaksikkuus. Lihakset ovat saavutuksen, toiminnan ja vallan merkki. BP-mies näyttää kuitenkin olevan varsin tyytyväinen vartaloonsa, vaikkei se perinteisen maskuliinisuuden ihannemittoja täytäkään.

Naisrepresentaatio myötäilee konventionaalista kauneusihannetta. Kampaus, ruumiin asento, eleet, tilanteen ja paikan mukaisen pukeutumiskoodin noudattaminen konnotoivat lisäksi hillittyä tyylikkyyttä, asiallisuutta ja muodollisuutta. Samanlaisia konnotaatioita synnyttää ravintola. Se on paikka, jossa vietetään aikaa hyvästä ruoasta nauttien ja hillityn sivistyneesti keskustellen. Naisen ja ravintolan tyylit näyttävätkin olevan sopusoinnussa keskenään.

Myös miehen habitus ja hänen toimintaympäristönsä sointuvat yhteen. Tärkeimmät sisustuselementit miehen poikamiesasunnossa näyttävät olevan iso peili ja heijastuskykyinen leivänpaahdin. Yletön ja tyytyväinen viihtyminen näiden esineiden edessä viittaa miehen narsistisiin taipumuksiin. Merkitseviä yksityiskohtia miehen asunnossa ovat myös peiliä reunustava Dolly Parton -taulu ja American Gigolo -juliste. IImeisesti Richard Geren romanttinen roolihahmo, jota markkinoitiin ainakin vielä joitakin vuosia sitten naisten unelmien kohteena, on miehelle samaistumisen kohde, ellei peräti identiteetin perusta. Taulussa hymyilevä maanläheisellä imagolla varustettu amerikkalainen countrypoptähti on näkyvällä paikalla ilmeisesti kertomassa miehen naisihanteesta. 
Barthesin neljännen koodin, symbolien koodin, avulla voidaan tarkastella tekstin symbolirakennetta. Tämä rakenne muodostuu binaarisista oppositioista, vastakohtapareista (Barthes 1974, 17), jotka ovat useimmiten järjestäytyneet hierarkkisesti niin, että binariteetin toinen vastanapa on hallitsevassa asemassa. Tällaisia binaarisia vastakohtapareja ovat esimerkiksi korkea-matala, hyvä-paha, valo-pimeys ja mies-nainen. (Hall 1999, 82, 154; Emmison \& Smith 2000, 67.) Symbolikoodi asettaa yksittäiset seemit ja muut merkitsevät yksiköt paikalleen binaarisista oppositiopareista muodostuvaan tekstin symbolirakenteeseen. Näin yhtenäistämällä tekstin merkitsevät elementit voidaan eristää niiden yhteinen nimittäjä. Mainoselokuvissa tällaisena symbolisena viestinä voi olla esimerkiksi sellaisia asioita kuin terveys, kauneus, antoisat ihmissuhteet tai tarkemmin määrittelemätön "hyvä". (Blom 1998, 219-220; ks. myös Falk 1997, 83-86.)

Kaikki Barthesin koodit ovat siinä mielessä kulttuurisia, että kulttuuriset käytännöt ovat opettaneet meitä lukemaan niitä. Kuitenkin erityisen kulttuurisena voidaan pitää referenssikoodia, koska sen avulla tarkastellaan niitä kulttuurisia järjestelmiä (tieteellisiä, historiallisia, kirjallisia, moraalisia jne.), joihin tekstissä viitataan. Referenssikoodi vastaa osin käsitettä intertekstuaalisuus, johon kuuluu ajatus kulttuurista tekstuaalisen vuorovaikutuksen pelitilana, jossa jokainen teksti on välttämättä intertekstuaalinen. Millään tekstillä ei toisin sanoen ole autonomista olemassaoloa, vaan tekstit rakentuvat aina viittauksista ja lainauksista. (Veivo 1995, 64; Kuusamo 1996, 102.) Televisiomainonnassa intertekstuaalisuus ilmenee viittauksina esimerkiksi elokuviin, tieteisiin, sukupuolijärjestelmään, muotiin tai refleksiivisesti itse mainosgenren historiaan. Referenssikoodin avulla nämä viittauskohteet paikannetaan ja luetaan mainosten kommentit niihin. Kommentti voi olla esimerkiksi esioletus siitä, että naisten tulee olla miesten silmissä haluttuja. (Blom 1998, 222-223.)

BP-mainoksesta löytyy useita kaksiarvoisia vastakohtapareja. Sen symbolirakenne muodostuu muun muassa sellaisista binaarisista oppositioista kuin korkea-matala, maskuliinisuus-feminiinisyys, sovinnaisuus-epäsovinnaisuus, kontrolli-hillittömyys, tyylitaju-mauttomuus, itsevarmuus-epävarmuus ja fakta-fiktio. Nais- ja miesrepresentaation välillä voidaan nähdä traditionaalinen jako korkeaan ja matalaan kulttuuriin. Naishahmo edustaa ensin mainittua "hyvää makua", sovinnaisen hillittyä tyylitajua ja itsekontrollia niin ympäristön (hieno ruokaravintola) kuin hillityn olemuksensakin (vaatteet, kampaus, eleet) puolesta. Miesrepresentaatio puolestaan rakentuu merkitsijöistä, jotka edustavat populaarikulttuurin kuvastoa (Richard Gere, Dolly Parton, rock'n'roll, pikaruoka) ja sen eri tyylien hillittömän epäsovinnaista (ja postmodernia) sotkemista keskenään. Voidaan myös ajatella, että näiden kahden eri maailmoista olevien representaatioiden asettaminen rinnakkain alleviivaa miehen tyylitajuttomuutta.

Traditionaaliseen sukupuolijärjestelmään tässä mainoksessa viitataan leikittelemällä stereotyyppisellä maskuliinisuus-feminiinisyys-polariteetilla. Mainoksessa käännetään ylösalaisin stereotyyppinen käsitys maskuliinisuudesta ja feminiinisyydestä suhteessa ulkonäköön. Tässä miehen turhamaisuus, kiinnostus ulkonäköään kohtaan ja päättämättömyys sitä koskevien valintojen (pukeutumisen) suhteen johtaa siihen, että nainen joutuu odottelemaan miestä. Mies on "naisen paikalla" ihaillessaan itseään narsistisesti peilin edessä (vrt. Rossi 2003, 108). Polariteetissa itsevarmuus-epävarmuus mieshahmo sijoittuu selkeästi edelliseen, niin että itsevarmuus luisuu itsekeskeisyyteen, joka ohittaa kaiken muun. Miehen itseihailuun kietoutuu todellisuudentajun hämärtyminen, toden ja kuvitellun sekoittuminen. Mies ei oivalla tai suostu näkemään, ettei hän oikein täytä identiteettinsä rakentamisen perustana käyttämänsä romanttisen Hollywood-hurmurin mittoja. 
Mainoksen kaksi naisrepresentaatiota, ravintolassa odotteleva nainen ja Dolly Parton, edustavat erilaisia todellisuuksia ja poikkeavat tyyliltään toisistaan. Tekemällä Parton-representaation kautta näkyväksi miehen naisihanne, tullaan samalla alleviivanneeksi miehen ja ravintolassa istuvan naisen yhteensopimattomuutta. Ero näiden kahden naisrepresentaation ja niiden edustamien maailmojen välillä voi miehen narsismin ohella selittää sen, miksei hän lopulta saavukaan sovittuun tapaamiseen.

Mainoksen "sankari" on siis enemmän tai vähemmän mauttomasti erilaisia populaarikulttuurin tyylejä keskenään sekoitteleva, turhamainen, päättämätön, epäluotettava, itsekeskeinen, tyyli- ja todellisuudentajua vailla oleva kuvitelmiensa kanssa kotonaan viihtyvä anorektinen nuori mies. Miten mainoksen "hyvä" saadaan näkyviin tällaisen (joidenkin mielestä jopa vastenmielisiä assosiaatioita synnyttävän) representaation kautta? Mainoksen symbolista viestiä pohtiessa tulee väistämättä mieleen, että kyse täytyy olla vitsistä. Näyttääkin siltä, että tämän mainoksen "hyvä" on koomisuus.

\section{Koomisen mekanismit}

Mistä BP-mainoksen koomisuus syntyy? Millaisin keinoin katsojaa pyritään naurattamaan? Osin tähän vastasi jo edellinen merkitysanalyysi, mutta onko koomisen teorioilla antaa lisävalaistusta mainoselokuvien merkitystuotannon tarkasteluun?

Henri Bergson (2000/1900, 26-28, 39) esitti vuosisata sitten - teollistumisen kulttuurin ollessa vauhdissa - ajatuksen siitä, että kaikki komiikka perustuu viimekädessä mekaanisuuteen. Meitä naurattaa Bergsonin mukaan elollisen ylle levittäytyvä konemaisuus, toisto, jäykkyys ja automatisoituminen. Mekaaniselta vaikuttava elämä, elävän ruumiin jäykistyminen koneeksi on se, mistä naurumme syntyy. Osoituksena Bergsonin näkemyksen kohdallisuudesta on pidetty mykän elokuvan komedioita, erityisesti Chaplinin Nykyaikaa (Knuuttila 1992, 117). Nykyisen kulutus- ja mediakulttuurin kontekstissa teoria, joka palauttaa komiikan jäännöksettä toimijoiden ja toimintojen konemaiseen automatisoitumiseen, ei tunnu kovinkaan selitysvoimaiselta. Teoria on myös melko lailla hampaaton BPmainoksen komiikkaa analysoitaessa. Elollisen ylle levittäytyvää konemaisuutta koomisen synnyttäjänä ei tästä mainoksesta oikein löydy.

Sen sijaan inkongruenssin, yhteensopimattomuuden periaate näyttäisi selittävän osittain tämän mainoksen koomisuutta. Koomisen syntymekanismeja selittävissä malleissa on usein päädytty yleisluontoiseen ajatukseen siitä, että koominen vaikutelma syntyy epäsuhdasta tai ristiriidasta. Useimpien teorioiden mukaan lähes kaikki koominen perustuu inkongruenssiin, siihen, että yhdistetään yllättäviä asioita, saatetaan tuttu outoon valoon tai toimitaan konventioista poikkeavalla tavalla. (Olsen 1968; Neale \& Krutnik 1990, 67, 86; Knuuttila 1992, 112; Herkman 2000, 374.) Mainoselokuvissa inkongruenssin periaate toteutuu vaikkapa assosioimalla isän suorittama vauvan vaipanvaihto ja ruokinta F1-kilpaauton varikkopysähdykseen (Sarpavaara 2004, 124).

Seemien, binaaristen oppositioiden ja kulttuuristen referenssien tarkastelun kautta nousi BP-mainoksesta esiin poikkeamia ja epäsuhtaa. Mainoksessa koomista tuotetaan törmäyttämällä korkeaa ja matalaa: hillitty ja hienostunut ravintolakulttuuri vertautuu eri tyylejä railakkaasti yhdistelevään postmoderniin populaarikulttuuriin. Tämä epäsuhta tuodaan ilmi nais- ja miesrepresentaatioiden kautta. Inkongruenssilla pelataan myös asettamalla samalle viivalle romanttisen maskuliinisuuden ikoni (Gere) ja poikkeama (mainoksen päähenkilö) 
maskuliinisuuden traditionaalisesta kuvastosta. Koomista vaikutelmaa lisää se, ettei mies näytä havaitsevan epäsuhtaa itsensä ja idolinsa kautta välittyvän ideaalimaskuliinisuuden välillä. Yhteensopimattomuutta voidaan havaita myös mainoksen kahden naisrepresentaation välillä. Dolly Partonin rempseän maanläheinen hahmo vertautuu ravintolassa odottavan naisen hillittyyn eleganssiin. Näissä representaatioissa voi nähdä myös amerikkalaisen populaarikulttuurin ja eurooppalaisen (ravintola-) kulttuurin yhteentörmäyksen.

Koomisen vaikutelman yhtenä keskeisenä tekijänä on jo ainakin Aristoteleesta lähtien pidetty yllätystä. Vaikka yllätys ei sinänsä ole koomisen tae tai ehto, niin suuri osa koomisista tapahtumista ja vitseistä näyttää perustuvan sille. Koomisen yllätyksen lähde voi olla esimerkiksi poikkeaminen stereotyyppisistä sukupuolirooleista. (Neale \& Krutnik 1990, 43, 51; Knuuttila 1992, 89, 118.) Koska yllätystä ei ole ilman odotusta, voidaan puhua odotuskomiikasta, komiikasta joka liittyy odotuksissamme ennakoituun tulevaan (Freud 1983/1905, 173-174).

Mainoselokuvissa komiikkaa tuotetaan odotuksen täyttymättömyyden kautta muun muassa esittämällä erilaisia poikkeamia roolinmukaisesta käyttäytymisestä (Sarpavaara 2004, 125). BP-mainoksessa odotuskomiikkaa tehdään luomalla toiminnan ja tarinan tasolla odotus siitä, että mies saapuu sovittuun tapaamiseen. Näin ei kuitenkaan tapahdu, vaan kaiken valmistautumisen jälkeen mies jättää kauniin naisen yksin ravintolaan ja jää peilikuva ja einespitsa seuranaan kotiin. Yllättävää mainoksessa on myös poikkeamat miehekkyyden ja naisellisuuden konventionaalisista representaatioista.

Siinä missä inkongruenssi ja odotuskomiikka käyttävät konventioista poikkeamista koomisen synnyttämisessä, on parodian strategiana konventioiden liioittelu, niiden alleviivaaminen. Parodia on suurellinen tapa esittää kohde. Tämä ilmenee esimerkiksi sankarien "sankarillisuuden", roistojen "roistomaisuuden", romantiikan "romanttisuuden" tai mainosten "mainostettavuuden" viemisenä suhteettomaksi (vrt. Blom 1995, 41). ${ }^{2}$ Kuvaamalla hahmoja ja niiden toimintaa liioitellun konventionaalisesti voidaan rikkoa konventionaalisia vastakkainasetteluja ja osoittaa niiden naurettavuus (Neale \& Krutnik 1990, 18-19; Herkman 2000, 374).

Televisiomainoksissa parodia näkyy esimerkiksi seksikkyyden ja halun representaatioiden liioitteluna tai vaikkapa "väärään" sukupuolirooliin joutumisen synnyttämän avuttomuuden alleviivaamisena (Sarpavaara 2004, 125-126). BPmainoksessa parodia ilmenee ennen kaikkea liioittelevana tapana esittää miehen tyytyväisyys itseensä ja erityisesti ulkonäköönsä.

Varsinkin parodian kohdalla tulee eteen se, ettei mainosten luokitteleminen koomisiin ja ei-koomisiin ole aina ongelmatonta. Vaikka mainos suhteellisen kiistattomasti vetoaisi katsojien asialliseen tosikkomaisuuteen (esimerkiksi informoimalla mutkattomasti maissihiutaleiden ravinto-arvoista ja terveydellisistä vaikutuksista tai ylistämällä auton nautinnollisia ajo-ominaisuuksia), niin ironisella camp-asenteella varustettu katsoja voi nähdä siinä tahatonta komiikkaa. Vaikka unohtaisi kaiken ironisoivan lukutavan, niin siltikään ei ole aina selvää onko mainoksen komiikka tahatonta vai tarkoituksellista. Aina ei ole päivänselvää parodioidaanko mainoselokuvissa mainosten tapaa myydä tuotteita seksin avulla vai väitetäänkö niissä pokkana, että esimerkiksi imurin tai parranajokoneen hankkiminen lisää omistajansa seksuaalista attraktiivisuutta. Vaikka mitä tahansa tv-mainosta voidaan pitää enemmän tai vähemmän avoimena tekstinä, jonka tulkinta on sidoksissa katsojan kulttuuriseen kapasiteettiin, niin erityisesti parodian kohdalla on toisinaan vaikea sanoa parodioidaanko niissä vai ei esimerkiksi stereotyyppistä tapaa representoida seksikäs nainen. 
Eräs tapa tehdä komiikkaa on asettaa henkilö suhteeseen ylivoimaisen ulkomaailman kanssa. Henkilöstä saadaan naurettava osoittamalla, että hän on itse asiassa sätkynukke, joka luulee toimivansa vapaasti. (Bergson 2000/1900, 58-59.) Ylivoimaista ulkomaailmaa voivat edustaa yhteiskunnan normit ja pakotteet kuin myös henkilön omat ruumiilliset tarpeet (Freud 1983/1905, 173). Vaikkei BPmainoksessa välttämättä näy sätkynukkeja, niin ylivoimainen ulkomaailma siitä löytyy. Naishahmon näkökulmasta tällaiseksi maailmaksi osoittautuu mies ja erityisesti hänen narsisminsa, joka estää suunnitellun yhteisen illanvieton. Usein tvmainoksissa koomisuutta aiheuttava, esteitä toiminnalle asettava ulkomaailma on vahvasti kulttuuristen käytäntöjen, ideaalien ja normien maailmaa. Tätä maailmaa voi mainoksissa edustaa muun muassa konventionaalinen maskuliinisuus, perinteinen malli sukupuolten välisestä työnjaosta, ideaali hoikasta ruumiista ja vaatimus ulkonäön kohentamista. (Sarpavaara 2004, 127.)

Naurun lähde voi olla myös käänteinen maailma, jossa suuri on käännetty pieneksi, pieni suureksi, arvokas arvottomaksi, arvoton arvokkaaksi, vaarallinen vaarattomaksi, alhainen ylhäiseksi, ylhäinen alhaiseksi tai jossa ylipäätään roolit on käännetty toisin päin (Bergson 2000/1900, 69, 89-90; Knuuttila 1992, 106-107). Mainosten ylösalaisin käännetyssä maailmassa mies voi olla naisen avoimen arvioivan katseen kohteena, koneen arvo ohittaa ihmisen arvon tai keskeinen käänne elämässä jäädä uuden auton varjoon. Käänteisyys on tärkeä koomisen vaikutelman synnyttäjä myös BP-mainoksessa, jossa miehisyyden ja naisellisuuden stereotyypit ovat vaihtaneet paikkaa. Tässä mainoksessa stereotyyppinen kuva turhamaisesta, ylenpalttisesti ulkonäöstään kiinnostuneesta ja tämän tähden myöhästelevästä naisesta käännetään ylösalaisin asettamalla mies toimimaan tämän kuvan mukaisesti.

Komiikkaa voidaan tehdä myös paljastamalla, että henkilö on jotain muuta kuin mitä hän uskottelee olevansa. Tätä mekanismia muun muassa Freud $(1983 / 1905,177)$ on kutsunut naamion riisumiseksi. Siitä on kyse esimerkiksi silloin kun osoitetaan, että henkilö on petoksella hankkinut itselleen kuulumatonta kunniaa ja arvovaltaa. Näytetään, että puolijumalana ihailtu henkilö on sittenkin aivan samanlainen inminen kuin muut. BP-mainoksessa ei naamion riisumista näytetä. Voidaan kuitenkin ajatella, että tarinan alussa mies, sopiessaan yhteisestä illanvietosta, on uskotellut naiselle olevansa jotain muuta kuin mitä tässä mainoksessa saamme nähdä. Eksplisiittisemmin naamion riisuminen on esillä esimerkiksi Edet-wc-paperimainoksessa (ks. Sarpavaara 2004, 128, 183). Mainoksen alussa nuori mies, nuori nainen ja vanhempi mies istuvat vierekkäin elokuvateatterissa. Keskellä istuva nuori mies on valmistautunut elokuvailtaan tunkemalla paitansa alle wc-paperia näyttääkseen lihaksikkaammalta. Elokuva liikuttaa naisen kyyneliin. Topattu mies tarjoaa naiselle turvallista kainaloa, jolloin nainen osoittaa huomanneensa huijauksen vetämällä miehen paidan alta esiin pehmeää paperia pyyhkiäkseen kyyneleensä. Miehen toisella puolella istuva iäkäs mies nukahtaa nuoren miehen pehmeää olkapäätä vasten. Mainoksen komiikka perustuu vahvasti siihen, että nuori mies uskottelee naiselle omaavansa tuskalla ja hiellä hankitun kovan ja kiinteän kehon, joka viittaa mielikuviin kreikkalaisista jumalista ja yli-ihmisistä (vrt. Dyer 2002, 218-220) mutta joka paljastuukin pehmeäksi ja arkiseksi, ei-jumalalliseksi wc-paperihuijaukseksi.

Koomisen tunnistaminen on aina sidoksissa sosiaalisiin, kulttuurisiin ja historiallisiin käyttö- ja toimintakonteksteihinsa ja niiden mahdollistamiin tulkinnallisiin valmiuksiin. Erityisesti tämä pätee ironiaan, jossa ei välttämättä itsessään ole mitään, mikä takaisi, että se tunnistetaan ironiaksi. Ironia voidaan määritellä tuotetuksi monimielisyydeksi, jossa näytetään sanovan yhtä, mutta tarkoitetaan itse asiassa jotain muuta. (Lehtonen 1998, 140-141.) Näyttäisi siltä, että BP-mai- 
noksessa ei tätä koomisen mekanismia käytettäisi. Mainos tarkoittaa sitä, mitä se sanoo. Viestiin "tämä herkullinen ja nopeasti nautittava pitsa on tehty sinulle, joka haluat enemmän aikaa keskittyä juuri siihen mistä olet kiinnostunut" ei sisälly kätkettyä ivaa. Henkilöhahmojen koominen kuvaus on tässä lähempänä parodiaa, liioittelua.

\section{Lopuksi}

Artikkelissa olen tarkastellut tapaustutkimuksen keinoin nykymainonnan merkitystuotannossaan käyttämää komiikkaa. Komiikan käyttöä olen tutkinut erityisesti sen suhteen, miten se kytkeytyy sukupuolen esittämiseen. Semioottisen merkitysanalyysin ja komiikan teorioiden avulla olen etsinyt vastauksia kysymykseen, miten ja millaisia esityksiä sukupuolesta komiikan keinoin BP-mainoksessa rakennetaan.

Kysymykseen vastaamista voidaan vielä tarkentaa ottamalla käyttöön funktionäkökulma. Komiikan funktiot voidaan jakaa vallitsevan järjestyksen suhteen kahteen ääripäähän - järjestystä vahvistavaksi tai sitä muuttamaan pyrkiväksi.

Bergsonin (2000/1900, 19-20, 64, 136-139) näkemyksessä korostuu ensin mainittu: hänen mukaan nauru on oikaisu, joka alleviivaamalla epätäydellisyyttä havahduttaa ihmiset hereille, herättää pelkoa ja tukahduttaa näin poikkeavuuksia. Yhteiskunta vastaa itseään kohtaan kohdistuneeseen julkeuteen naurulla, jossa ei ole mitään hyväntahtoista vaan tarkoituksena on nöyryyttää ja antaa kohteelle tuskallinen olo. Jo ennen Bergsonia Descartes korosti naurun rankaisevaa ja kohti sopivaa opastavaa tehtävää (Knuuttila 1992, 89-90). Samansuuntaisia ajatuksia löytyy myös Peter L. Bergeriltä ja Thomas Luckmannilta (1995/1966, 175-176), jotka huomauttavat, että naurunalaiseksi joutuminen on yhteiskunnallinen sanktio, jonka tarkoitus on viimekädessä jokapäiväisen elämän todellisuuden ylläpitäminen ja todellisuutta murentavien epäilysten torjuminen.

Koomisella ja naurulla voidaan asettua myös vallitsevaa järjestystä vastaan. Koominen tarjoaa mahdollisuuden purkaa valtasuhteita, haastaa vallitsevia totuuksia ja kyseenalaistaa stereotyyppejä (Lehtonen 1995, 149, 164-178). Vaikkei valtasuhde komiikan käsittelyssä katoaisikaan, voidaan se tällä tavalla kuitenkin tehdä näkyväksi (Aro 2003, 8). Mihail Bahtin (1995/1965, 11, 83) kirjoittaa kansan naurusta, joka tuhoaa kuvitelmat ehdottoman välttämättömistä arvoista ja vapauttaa tehden tilaa uusille mahdollisuuksille. Keskiaikaisissa karnevaaleissa tämä toteutui groteskilla naurulla, jolla kumottiin hierarkkiset suhteet, etuoikeudet, normit ja kiellot ja vapauduttiin tilapäisesti vallitsevasta järjestyksestä ja totuudesta.

Myös mainoselokuvissa komiikka voi palvella niin vallitsevan järjestelmän vahvistamista kuin sen - ainakin häivähdyksenomaista - kyseenalaistamista. Laajemmin koomisten mainoselokuvien kuvastoa sukupuolijärjestelmän näkökulmasta tutkiessani (Sarpavaara 2004) löysin pääsääntöisesti perinteisen sukupuolijärjestelmän mukaisia representaatioita. Tv-mainonnassa perinteistä kuvaa naiseudesta vahvistetaan esimerkiksi sijoittamalla nainen traditionaalisen työnjakomallin mukaisesti kodin piiriin huolehtimaan lastenhoidosta ja perheen ruokahuollosta. Perinteistä naiskuvaa uusinnetaan myös turhamaisten ja romanttiseen haaveiluun taipuvaisten naisten representaatioilla. Vaikka nämä esitykset saatetaan asettaa hymähtelyn kohteeksi, niin niitä ei kuitenkaan kyseenalaisteta, vaan todetaan essentialistiseen tyyliin että "juuri tällaisiahan naiset ovat". Konventionaalista kuvaa mieheydestä puolestaan uusinnetaan muun muassa yhdistämällä miesrepresentaatioihin sellaisia asioita kuin ura, moottoriurheilu ja poikien 
kohdalla kura. Uusintamista tapahtuu myös nauramalla stereotyyppisen maskuliinisuuden negaatioille, esimerkiksi parodioimalla ruoanlaittoa yrittävää isää. Jonkin verran mainoselokuvissa esiintyy myös perinteisen sukupuolijärjestelmän horjuttamista. Mainoksessa esimerkiksi saatetaan uskotella, että tuotteen käyttö edistää tasa-arvoisempaa työnjakoa miesten ja naisten välillä.

Tässä analysoitu BP-mainos edustaa ambivalentteja representaatioita sisältäviä mainoselokuvia, joissa komiikan keinoin sekä myötäillään että joltain osin kyseenalaistetaan perinteisen sukupuolijärjestelmän kuvastoa. Tällaisissa mainoksissa saatetaan mainostaa esimerkiksi siivousvälineitä niin, että mainoksen alussa isä ja poika ovat pesemässä yhdessä kodin lattioita, mikä voidaan nähdä perinteisen maskuliinisuuden ja työnjakomallin kuvastosta poikkeavana toimintana. Mainoksen lopussa siivoojien maskuliinisuus kuitenkin varmistetaan ja heidät liitetään perinteiseen mieskuvastoon laittamalla heidät pelaamaan jääkiekkoa. (Sarpavaara 2004, 133.) BP-mainoksessa ambivalenssi ilmenee niin ikään miesrepresentaation kautta. Perinteisestä mieskuvastosta tämä representaatio poikkeaa ensinnäkin ruumiillisuuden suhteen: vaikkei BP-mies omistakaan vallan ja saavutusten merkkinä toimivaa, ideaalimaskuliinisuuden mukaista lihaksikasta ruumista vaan sen lähes täydellisen vastakohdan, on hän jopa narsistisen tyytyväinen kehoonsa. Toinen poikkeama liittyy stereotyyppisen maskuliinisuusfeminiinisyys-polariteettikäsityksen ylösalaisin kääntämiseen. Tässä mainoksessa miehen ja naisen paikat ovat vaihtuneet: miehen turhamaisuus, päättämättömyys ja kiinnostus omaa ulkonäköä kohtaan saavat aikaan sen, että stereotypian vastaisesti nainen on se osapuoli, joka joutuu odottelemaan. Toisin sanoen BPmainoksen miesrepresentaatio näyttäytyy poikkeamana perinteisestä sukupuolikuvastosta liittäessään mieheyteen elementtejä stereotyyppisestä naiseudesta. BP-miestä ei kuitenkaan tarjota kovinkaan houkuttelevana samaistumisen kohteena, vaan tämä poikkeama perinteisestä mieskuvastosta asetetaan parodiseen valoon. Näin mainoksessa tullaan negaation kautta uusintaneeksi perinteistä käsitystä mieheydestä osoittamalla, millaisista elementeistä se ei rakennu.

Komiikan keinoja hyödyntävissä mainoselokuvissa perinteistä sukupuolikuvastoa haastavat esitykset ovat olleet melko harvassa. Erityisesti perinteinen kuva mieheydestä on pitänyt pintansa. Ylipäätään vallitsevien totuuksien haastamiseen, emansipaatioon, valtasuhteiden purkamiseen ja stereotyyppien kyseenalaistamiseen tv-mainosten komiikassa törmää harvoin. (Sarpavaara 2004, 131133.) Näyttääkin siltä, että koomiset mainoselokuvat tulevat sukupuoliteknologiana pääsääntöisesti uusintaneeksi perinteisiä käsityksiä naiseudesta ja mieheydestä.

Osittain tätä selittää varmastikin se, että stereotyyppinen kuvausperinne on vakiintunut komiikan genreen sen verran lujasti, että sen haastaminen on vaikeaa ja hidasta (vrt. Herkman 2000, 381). Toinen selitys koomistenkin mainoselokuvien stereotyyppisyydelle voisi olla se, että näiden lyhytelokuvien tekijöiden on luotava helposti ja äkkiä tunnistettavia henkilöhahmoja. Tällaisiahan stereotyypit ovat. Kuitenkin se, että kaupallisia tarkoitusperiä palvelemaan tuotetuissa koomisia elementtejä sisältävissä mainoselokuvissa ylipäätään esiintyy, vaikkakin vähemmän, myös kuvia, jotka eivät ole linjassa perinteisen sukupuolijärjestelmän kanssa (ks. Sarpavaara 2004, 130-141), kertoo siitä, ettei stereotyyppisen kuvausperinteen haastamien ja uudenlaisten representaatioiden tuominen kuvastoon komiikan keinoin ole mahdotonta. Olkoonkin, että tämä saattaa tapahtua BP-mainoksen tavoin ambivalenttina ja camp-henkisenä leikittelynä sukupuolistereotypioilla. 


\section{Viitteet}

1 Tutkimusaineisto ja mainoselokuvien luokitteluperiaatteet tapauslistana ks. Sarpavaara 2004, liite 3

2 Itse asiassa Virpi Blom määrittelee näin ironian, mutta nähdäkseni tämä määritelmä voisi kuvata parodiaa, joka sanakirjan (CD-perussanakirja 1997) mukaan on kirjallisuuden laji tai tuote, jossa jokin yleisesti tunnettu aihe tai teos tehdään naurunalaiseksi sen ominaispiirteitä ivallisesti mukailemalla. Ironian kyseinen sanakirja määrittelee (sala)ivaksi. Ironiaan siis sisältyy jotain kätkettyä ja parodiaan korostettua, alleviivattua.

\section{Kirjallisuus}

Aro, Jari (2003)

Mitä yhteistä on miehillä ja sukkahousuilla? Huomioita sähköpostihuumorista. Mediumi 2.2

[www-dokumentti]. http://www.m-cult.net/mediumi/ (luettu 20.5.2005).

Bahtin, Mihail (1995/1965)

Francois Rabelais - keskiajan ja renessanssin nauru. Helsinki: Taifuuni.

Barthes, Roland (1974)

S/Z. New York: Hill and Wang.

Berger, Peter L. \& Luckmann, Thomas (1995/1966)

Todellisuuden sosiaalinen rakentuminen. Tiedon sosiologinen tutkielma. Helsinki: Gaudeamus.

Bergson, Henri (2000/1900)

Nauru. Tutkimus komiikan merkityksestä. Helsinki: Loki.

Blom, Virpi (1995)

Levisten lupaukset. Tiedotustutkimus 18: 4, 25-42.

Blom, Virpi (1998)

Onko mainoksella merkitystä? Mainosten tulkinta Roland Barthesin koodiston avulla. Teoksessa Kantola, Anu; Moring, Inka \& Väliverronen, Esa (toim.) Mediaanalyysi. Tekstistä tulkintaan. Helsingin yliopiston Lahden tutkimus- ja koulutuskeskus

Butler, Judith (1990) Gender Trouble. Feminism and Subversion of Identity. London: Routledge.

CD-perussanakirja (1997) Kotimaisten kielten tutkimuskeskuksen julkaisuja 94. Oy Edita Ab.

Dyer, Richard (2002)

Älä katso! Seksuaalisuus ja rotu viihteen kuvastossa. Tampere: Vastapaino.

Eco, Umberto (1985)

Matka arkipäivän epätodellisuuteen. Helsinki: WSOY.

Emmison, Michael \& Smith, Philip (2000)

Researching the Visual. Images, Objects, Contexts and Interactions in Social and Cultural Inquiry. London: Sage.

Falk, Pasi (1997)

The Genealogy of Advertising. Teoksessa Pekka Sulkunen \& John Holmwood \& Hilary Radner \& Gerhard Schulze (eds.) Constructing the new consumer society. London: Macmillan.

Frangén, Simo (1990) Komiikka kritiikkinä - naurettava yritys? Pro gradu -tutkielma. Tampereen yliopisto, sosiologian ja sosiaalipsykologian laitos, sosiologia.

Freud, Sigmund (1983/1905)

Vitsi ja sen yhteys piilotajuntaan. Helsinki: Love.

Hall, Stuart (1999)

Identiteetti. Tampere: Vastapaino.

Herkman, Juha (2000)

Huumorin ja vallan keskeneräinen kysymys: populaarin kokemuksen jäljillä. Teoksessa Koivunen, Anu;

Paasonen, Susanna \& Pajala, Mari (toim.) Populaarin lumo - mediat ja arki. Turku: Turun yliopiston taiteiden tutkimuksen laitoksen julkaisuja, sarja A, n:o 46.

Jhally, Sut (1987)

The Codes of Advertising. Fetishism and the Political Economy of Meaning in the Consumer Society. New York: Martin's Press.

Knuuttila, Seppo (1992)

Kansanhuumorin mieli. Kaskut maailmankuvan aineksena. Helsinki: SKS.

Kuusamo, Altti (1996)

Tyylistä tapaan. Semiotiikka, tyyli, ikonografia. Helsinki: Gaudeamus.

de Lauretis, Teresa (1987)

Tecnologies of Gender. Essays on Theory, Film, and Fiction. Bloomington: Indiana University Press

Laurila, K. S. (1918)

Estetiikan peruskysymyksiä. Helsinki: WSOY

Lehtonen, Mikko (1995)

Pikku jättiläisiä. Maskuliinisuuden kulttuurinen rakentuminen. Tampere: Vastapaino. 
Lehtonen, Mikko (1998)

Merkitysten maailma. Kulttuurisen tekstintutkimuksen lähtökohtia. Tampere: Vastapaino.

Malmelin, Nando (2003)

Mainonnan lukutaito. Mainonnan viestinnällistä luonnetta ymmärtämässä. Helsinki: Gaudeamus.

Neale, Steve \& Krutnik, Frank (1990)

Popular Film and Television Comedy. London: Routledge.

Olsen, Elder (1968)

The Theory of Comedy. Bloomington: Indiana University Press.

Rossi, Leena-Maija (2003)

Heterotehdas. Televisiomainonta sukupuolituotantona. Helsinki: Gaudeamus.

Sarpavaara, Harri (2001)

Esityksiä ruumiillisuudesta. Nautinto, kurinalaisuus, voima ja huolenpito television mainosfilmeissä.

Lisensiaatintyö: Tampereen yliopisto, sosiologian ja sosiaalipsykologian laitos.

Sarpavaara, Harri (2004)

Ruumiillisuus ja mainonta. Diagnoosi tv-mainonnan ruumiillisuusrepresentaatioista. Tampere: Tampere University Press.

Veivo, Harri (1995)

Roland Barthes - tutkijan vallattomuus. Teoksessa Kantokorpi, Mervi (toim.) Kuin avointa kirjaa.

Leikkivä teksti ja sen lukija. Helsingin yliopiston Lahden tutkimus- ja koulutuskeskus. 